\title{
Man-Made Wildlife Tourism Destination: The Visitors Perspective on Lok Kawi Wildlife Park, Sabah, Malaysia
}

\author{
Boyd Sun Fatt ${ }^{1}$, Cindy Johnny ${ }^{1}$, Shirley M. Bakansing ${ }^{2}$ \\ ${ }^{1}$ Faculty of Hotel \& Tourism Management, University Teknologi MARA (UiTM), Sabah Branch \\ ${ }^{2}$ School of International Tropical Forestry, Universiti Malaysia Sabah (UMS), Sabah
}

\begin{abstract}
Sabah is blessed with natural forest habitats and rich with floras and faunas. Amongst its' attraction is wildlife endemism. Lok Kawi Wildlife Park was established to provide an alternative wildlife tourism destination with its inhabitants from the wildlife species of Borneo. Since its opening in 2007, multitudes of tourists have visited the park. However, there has been no study to identify the visitor's perspective on Lok Kawi Wildlife Park as man-made wildlife tourism destination. The study aims to assist the park's management for the betterment of the park's facilities and future development. A convenience sampling and a designed questionnaire was applied in this study, distributed after the visitors visited the park. The results showed that majority of the visitors were Malaysian and only a quarter were foreign visitors. Majority indicated that visiting the park is for recreational outing (holiday) and only a few indicated that is an educational visit. Majority of the respondents knew the meaning of wildlife tourism and visiting the park's is part of wildlife tourism. Most of the respondents came to know about the park's existence through the local media and mostly agreed that the park indeed provide an authentic learning experience about wildlife, whilst creating wildlife conservation awareness.
\end{abstract}

\section{Introduction}

Tourism has become a popular worldwide leisure activity. According to the UNWTO 2012 report showed that there were over 705 million international tourist arrivals globally, with a growth of USD950 billion in 2011, 4\% higher as compared to 2011 [1]. In Malaysia, approximately 25 million tourist arrivals were recorded year 2011 until November 2012 which an increase of $12 \%$ [2]. Malaysian government has incorporated tourism as one of the important sector of her industry and as an income generating industry in her economy. There are several benefits which strengthen the country economic from tourism industry, such as foreign exchanges, trading activities, as well as creating job opportunities for the local communities. In 2012, the tourism receipts alone has generated around USD25 billion (RM60 billion) to the Malaysia economy [2]. Meanwhile, Sabah (one of the state in Malaysia) reaped over RM3 billion in tourism receipts in 2012, accounting for $13.6 \%$ of the state's GDP [3]. Floras and faunas are the main attractions for local visitors, as well for foreign visitors who adored nature in Sabah. Sabah (located in Northern Borneo, East Malaysia) is also commonly 
known as land of biodiversity. The state is covered by mountainous terrain with abundant tropical rainforest, long white sandy beaches and coastlines, and the most spectacular coral reefs and marine life. Its wildlife diversity is one of the major tourist attractions to Sabah. Tourists arrivals to Sabah (either domestics or foreign) have also shown significant increased. From 2008 until 2012, approximately 5 million tourists have visited Sabah and with a corresponding RM10 billion in tourism receipts, which shown an annual growth rate of $13.5 \%$ over the last 6 years [4]. The Sabah state government has established and developed several areas such as Kinabalu Park, Sepilok Orang Utan Rehabilitation Centre, Tenom Agricultural Park, Tunku Abdul Rahman Park Island, Sipadan Island, and Lok Kawi Wildlife Park to support tourism sector in Sabah.

\section{Problem Statement and Objectives of the Study}

Captive wildlife tourism is increasingly becoming a popular recreational pursuit, largely among the residents of Kota Kinabalu, Sabah. Captive wildlife tourism is a form of viewing wild animals in a man-made confinement such as zoos, wildlife parks, animal sanctuaries or aquaria. Captive wildlife tourism, moreover, has been associated with nature tourism where visitors' experience the wildlife confinement in a natural setting. The main focus of the visitors to come to these places is because of their interest in wildlife and encountered with wild animals is partly of wildlife experience. In addition, the significant establishment of this captive or man-made wildlife tourism is to create a mutualistic relationship between tourism and nature conservation. Another main function of this establishment is to become a centre to influence public knowledge towards conservation, while enjoying and pursuing recreation activities. Despite the importance of the establishment of the park for recreation and wildlife tourist attraction, there has been no formal study on this topic particularly to Lok Kawi Wildlife Parks. Other studies conducted at Lok Kawi Wildlife Park focused more on the animals' habitat, visitors' satisfaction and willingness to pay (WTP). Thus, the main objective of the study is to determine the visitor's perception on the Lok Kawi Wildlife Park as man-made wildlife tourism destination.

\section{Description of Study Area and Methodology}

Lok Kawi Wildlife Park was formerly part of Lok Kawi Rubber Plantation land, owned by Lok Kawi Investment Limited, a British company in London. The Sabah state governments purchased the land and allocated 194.08 acres for Zoology Park and 50.53 acres for bird sanctuary. Both pieces of land were gazetted by the state government on 28 October 1996 and named Lok Kawi Wildlife Park. It's long term development is currently being managed by Sabah Wildlife Department. The Lok Kawi Wildlife Park is located along the old Penampang-Papar road near the township of Lok Kawi, and $20 \mathrm{~km}$ from Kota Kinabalu capital city of Sabah. Ever since it's official opening on 17 February 2007 until 2011, there were about 300,000 local visitors and 40,000 foreign visitors who visited the park (Visitors' record of Lok Kawi Wildlife Park, 2012). The Lok Kawi Wildlife Park consisted of a zoo and botanical garden covering an area of 280 acres. There were over 100 species of animal exhibit in the park. Many of them native to Sabah's tropical forest. The main highlight of the park would be the Borneo elephant, orang utan and proboscis monkey which are endemic species to Borneo Island. Other wild animals on display are the Malayan tiger, Malayan sun bear, Sumatran rhinoceros, Borneon wild cattle (Tembadau), sambar deer, Borneon gibbons, barking deer, hornbills, clouded leopard and many more [5]. A convenience sampling (non-probability method) was applied in this study. A questionnaire survey was the main tool in data collection. The questionnaire forms were distributed to the visitors after their visit the park's at the exit point. A total of 200 respondents were collected throughout the study period. 


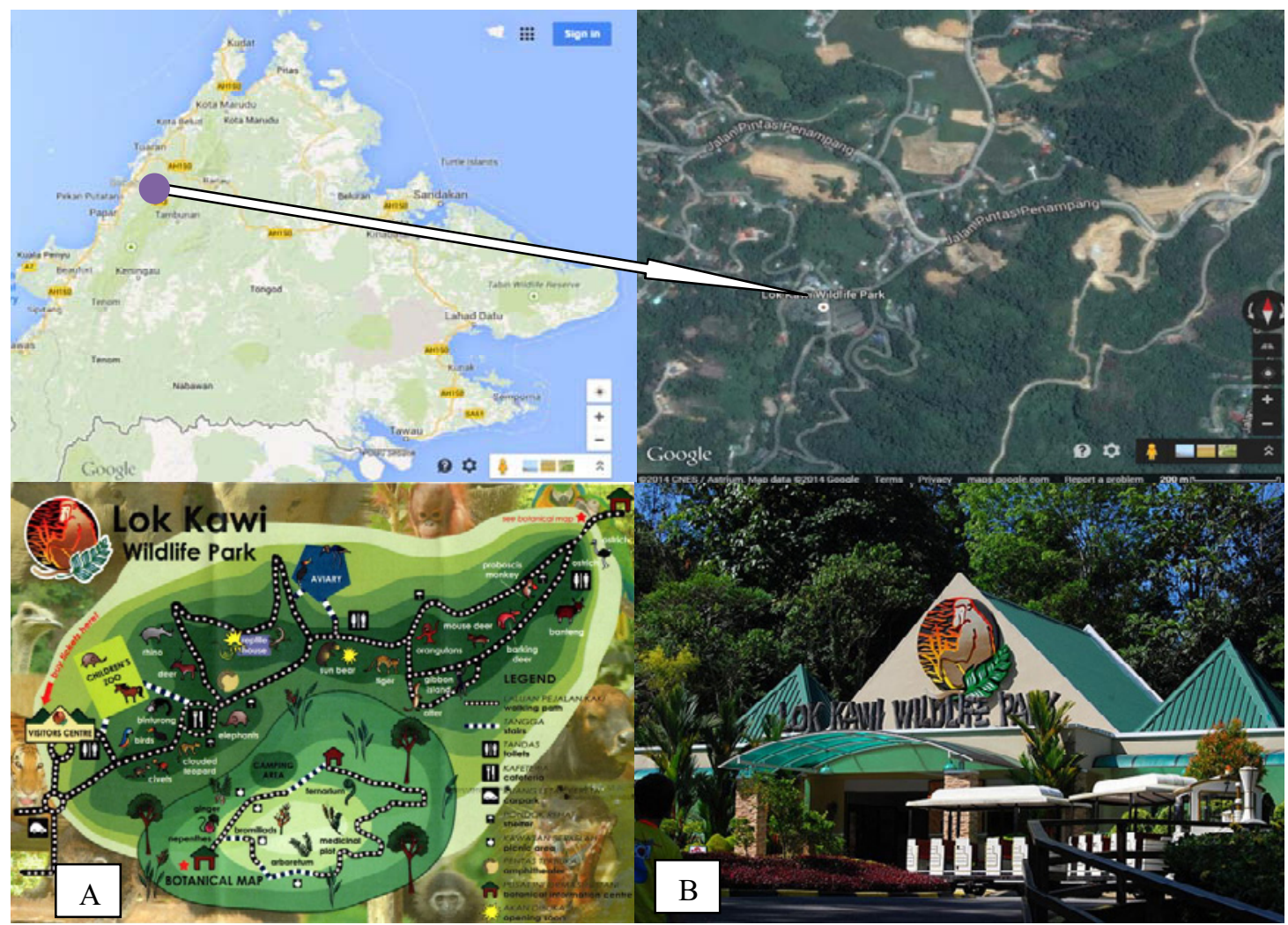

Figure 1. The study area map of Lok Kawi Wildife Park, Sabah (not according to scale). (A) Layout of Lok Kawi Wildlife Park, and (B) The entrance.

\section{Literature Review}

Wildlife tourism is tourism based on encounters with non-domesticated animals, and these encounters can occur either in the natural environment or in captivity. Wildlife tourism can be defined as "tourism undertaken to view and/or encounter wildlife. It takes place in a range of settings, from captive, semi-captive, to in the wild and it encompasses a variety of interactions from passive observation to feeding and/or touching the species viewed" [6]. In this case, visitors on the tour in the nature area are prohibited to touch or feed the wild animals and should be remained and treated as wild animal. Wildlife tourism brings about the contribution to conservation and community projects in developing countries. It also promotes environmental educations and awareness through standard operating procedures developed for wildlife tourist as well as for the various stakeholders in tourism. [7]. Wildlife tourism is also partly nature-based that may involve an element of adventure travel, and shares some of the key characteristics of ecotourism. Hence, wildlife tourism occurs in the natural setting is referred to as tourism in the wild. In fact, tourism experience that is based on wildlife is a component in wildlife tourism. Often wildlife tourism become an educative and/or interpretive and fosters supporting practices of conservation. For instance, a study done in Australia on 50 visitors of the Australian Northern Territory has showed that visitors were preferred seeing crocodiles in their natural environment [7]. The explanation of wildlife tourism, therefore, is a sustainable tourist activity undertaken to view and/or interact with wildlife in a range of settings. Zoos, however, endeavour to meet their conservation role through captive breeding, education, research, environmental enrichment, and support conservation of species and their habitats. Zoo tourism (also known as captive wildlife 
tourism) can be a tool in promoting biodiversity conservation, especially through education and interpretation [9]. In addition to conservation, education and research, zoo's has also to accommodate as recreation justification. The setting of the zoo's provide a pleasant setting for tourists, local visitors and family outings, as for entertain and support conservation [10]. Furthermore, the kind of wildlife tourism that provides environmental interpretation and adopts environmentally friendly practices through specific nature based activities, it is known as a form of special interest tourism [11].

The human-wildlife tourism activity requires an understanding of the interaction between humans and wildlife on the basic scientific discipline of wildlife biology and action of wildlife management. It is also noted by several authors that visitor's enjoyment and interest are more enhanced when the wildlife consists of infant animals and larger animals [12]. Example of such visitor's enjoyment and excitement can be seen in Jersey Zoo where visitors enjoyed the larger primates, bears and baby animals [13]. Wildlife biology enlightens the actions of the animals themselves through studies of their ecology and behavior. Whilst, wildlife management is concerned with the application of the wildlife biology findings with the purpose to manipulate or conserve wildlife populations and with the social, legal and political contexts that will contribute to the management decision [14]. Together, the science and management will recommend how interactions between people and wildlife can be arranged to maximize the benefits and minimize the problems for all parties, especially the tourism perspective. It is essential that the basic understanding of wildlife biology will enhances pleasure in the wildlife tourism experience by explaining animal's behavior and habitat, while, an understanding of wildlife management will help into management decision-making particularly in the tourism industry. In wildlife tourism, environment interpretation is almost likely being used in the tourism setting. However environment interpretation differs from environmental education. Environment interpretation is that to provide in an informal fashion to people who are at leisure state, whereas environment education is more formal approach emphasizes in learning experience without putting enjoyment as element in interpretation [15]. Nevertheless, interpretation is also associated with education that to provide visitors with sufficient information to further educates themselves with the aim of encouraging the development of a conservation ethic in sustainable wildlife tourism, without scarifying the component of enjoyment [16]. A study on visitors on the Great Barrier Reef has showed that bird watchers (made up 20\% of the 3000 visitors) surveyed indicating them being more of educational holiday seekers and have a high level of interest in interpretive activities [17]. In addition, the environment interpretation evaluation research in zoos also revealed that there was evidence that zoo interpretation programs can be successful in encouraging greater knowledge of wildlife and awareness of wildlife conservation issues [18].

\section{Results and Discussions}

A total of 200 respondents were collected throughout the study period, with the majority of the respondents of $84.5 \%$ were Malaysians and $15.5 \%$ foreign tourists. The ratio of local to foreign was correspondence with the total visitors in the whole year of 2008 , which is about $3: 1$. Out of $84.5 \%$ respondents, a total of $75.5 \%$ were visitors from the state of Sabah, whilst the remaining $24.5 \%$ were local tourists from other parts of Malaysia (Appendix 1). Meanwhile, data indicate that a total of 13 nationalities from Europe and Asia visited the park. With the majority being British constituting $19.4 \%$ of the total number of international visitors, $16.1 \%$ Japanese and $9.7 \%$ each for Denmark, Brunei and UK, respectively (Appendix 2).

There were a variety of outcomes by the respondents on other facts pertinent to the betterment of the overall visitor's experience that could very well benefit the park's management as presented in Appendix 3. Questions with regards to accessibility of the park to its visitors, purpose of the park and availability of information with regards to conservation and wildlife are posed to the respondents and the following are the findings. Based on the data gathered, $55 \%$ of the visitors came using their own transport with the remainder through public transport, and $38 \%$ of the visitors are repeat visitors. For the time being, only charted public transportation can be utilized to reach the park and this often quite pricey. The management may want to consider arranging a cheaper alternative such as public bus to 
route the area so that bringing more visitors especially low budget and backpack travelers. The data also shows that $68 \%$ of the respondents came to know about the park through family and friends and more than half came with either friend or their families for the visit. Another interesting fact is that $48 \%$ of the respondents came in as part of their tour package and this shows that tour agencies can play an important role in promoting the park as a wildlife destination. The data also reveals that $57 \%$ of the respondents came to the park as one of their leisure activity and the remaining came to actually find out more about the exotic Borneon wildlife that are being displayed in the park. An important revelation which is crucial to wildlife conservation is the fact that a majority of the respondents are aware of the importance of conservation and wildlife, however, an astonishing over $80 \%$ are unable to identify a good source of information with regards to conservation and wildlife. Findings on the visitors' overall perception towards Lok Kawi Wildlife Park as a man-made wildlife tourism destination, where questions with regards to the suitability or adequacy of the various activities within the park with regards to wildlife conservation are posed to the respondents (Appendix 4). The data showed that a majority the respondents agreed with the park being a wildlife tourism destination and various conservation activities are carried out by the park, with a standard deviation of 41.5 and 35.8 respectively. This is supported further by $84 \%$ of the respondent with a standard deviation of 40.1 , agreeing that a visit to the park is tactful in creating wildlife conservation awareness amongst its visitors. The overall visitors also agree that the life-animals entertainment indeed to support and creating wildlife awareness and part of wildlife tourism effort. The suitability of the entrance fee and the animal shows conducted by the park as part of their conservation effort were also posed to the respondents, and a majority of the respondents are supportive of such activities. The data also shows the respondents agreeing that a visit to the park enables the respondents to learn more about wildlife conservation and protecting wildlife can also be done hand in hand with tourism. In other words, the park's management indeed able to incorporated between the science and management, and able to arrange the interactions between people (visitor) and wildlife thru the setting of the park's itself. It is no doubt that the management of the park understands the principles of wildlife management particularly in the wildlife tourism industry. Nevertheless, the setting-up of environment interpretation that associated with public education has provided visitors with adequate information towards animals in the park's and also included component of enjoyment during their visit.

\section{Conclusion}

The findings of this study revealed that majority visitors of Lok Kawi Wildlife Park understand about the concept of wildlife tourism and its relation to conservation. Most of them perceived the park as a place where they can observed, learn and appreciating the value of wildlife in a safer environment close to city area. Although the park starts operating less than 6 years back, it obviously plays a significant role in promoting not only wildlife as a tourism product but also awareness to conserve these animals for future generation. However, more efforts need to be done to educate public who are yet unaware on the major aims of the park's development. Apart from the existing promotion and education programs, the management may want to improve its interpretative program and facilities. As difficult access may hinder certain group of visitors, providing cheaper public transportation as an alternative to reach the area should increase number of visitors. This may include students, low budget and backpacking tourists. Current practices of tour agencies to include Lok Kawi Wildlife Park as part of their itinerary should be further encourage and continue. As visitors perceptions may indicate their feeling about the way the park being managed, and what decision they will make in regard to it, long term monitoring program on visitors perception may be necessary.

\section{Acknowledgement}

Sincerest appreciations go to the management of Lok Kawi Wildlife Park and Sabah Wildlife Department, for their generosity in allowing conducting the research within the park itself. Acknowledge also extend to Ms. Yong Siew Kiing in helping gathering these data. 
Appendix 1: Malaysian respondents according to state.

\begin{tabular}{|c|c|c|}
\hline States & Frequency & $\%$ \\
\hline Sabah & 128 & 75.7 \\
\hline Sarawak & 16 & 9.5 \\
\hline Kuala Lumpur & 7 & 4.1 \\
\hline Johor & 7 & 4.1 \\
\hline Selangor & 2 & 1.2 \\
\hline Kedah & 2 & 1.2 \\
\hline Penang & 2 & 1.2 \\
\hline Perak & 2 & 1.2 \\
\hline Terengganu & 1 & 0.6 \\
\hline Labuan & 1 & 0.6 \\
\hline Pahang & 1 & 0.6 \\
\hline & 169 & 100 \\
\hline
\end{tabular}

Appendix 2: Foreign respondents according to country.

\begin{tabular}{|c|c|c|}
\hline Foreign Countries & Frequency & $\%$ \\
\hline British & 6 & 19.4 \\
\hline Japanese & 5 & 16.1 \\
\hline Denmark & 3 & 9.7 \\
\hline UK & 3 & 9.7 \\
\hline Brunei & 3 & 9.7 \\
\hline English & 2 & 6.5 \\
\hline Irish & 2 & 6.5 \\
\hline Hong Kong & 2 & 6.5 \\
\hline Danish European & 1 & 3.2 \\
\hline Australian & 1 & 3.2 \\
\hline Scottish & 1 & 3.2 \\
\hline Russian & 1 & 3.2 \\
\hline Sweden & 1 & 3.2 \\
\hline Total & 31 & 100.0 \\
\hline
\end{tabular}

Appendix 3: Overall correspondents in relation to Lok Kawi man-made wildlife park.

\begin{tabular}{llcc}
\hline \multicolumn{1}{c}{ Items } & & Freq & \% \\
\hline Types of transportation services to Lok Kawi Wildlife Park & Own Transport & 109 & 55 \\
& Public Transport & 86 & 43 \\
& Walk & 5 & 3 \\
\hline Frequent of visit to Lok Kawi Wildlife Park & 1 time & 124 & 62 \\
& 2 times & 44 & 22 \\
& 3 times & 13 & 7 \\
Accompany & More than 3 times & 19 & 10 \\
& Friends & 51 & 26 \\
& Family & 52 & 26 \\
Information regarding of the Lok Kawi Wildlife Park & Tour Group & 96 & 48 \\
& Individual & 1 & 1 \\
\hline
\end{tabular}




\begin{tabular}{llcc} 
& Friends & 109 & 55 \\
& Family & 25 & 13 \\
\hline Purpose of visit to Lok Kawi Wildlife Park & Education & 86 & 43 \\
& Holiday & 114 & 57 \\
\hline Understanding about Wildlife Tourism & Yes & 132 & 66 \\
& No & 68 & 34 \\
\hline Understanding about Conservation & Yes & 110 & 55 \\
& No & 90 & 45 \\
\hline \multirow{2}{*}{ Sources of Wildlife tourism information } & Television & 21 & 11 \\
& Internet & 2 & 1 \\
& At school & 2 & 1 \\
& Zoo Negara (Malaysia) & 3 & 2 \\
& Media & 5 & 3 \\
Sources of Conservation information & Not sure & 167 & 84 \\
\hline \hline
\end{tabular}

Appendix 4: The visitor's perception towards Lok Kawi man-made wildlife park as tourism destination.

\begin{tabular}{|c|c|c|c|c|}
\hline Items & & Freq & $\%$ & $\begin{array}{l}\text { Standard } \\
\text { Deviation }\end{array}$ \\
\hline \multirow{5}{*}{$\begin{array}{l}\text { The park's itself is a wildlife tourism } \\
\text { destination }\end{array}$} & Strongly disagree & 2 & 1 & \multirow{5}{*}{$41.5^{*}$} \\
\hline & Disagree & 7 & 4 & \\
\hline & Not sure & 28 & 14 & \\
\hline & Agree & 101 & 51 & \\
\hline & Strongly Agree & 62 & 31 & \\
\hline \multirow{5}{*}{$\begin{array}{l}\text { The park's carry out various conservation } \\
\text { activities }\end{array}$} & Strongly disagree & 2 & 1 & \multirow{5}{*}{$35.8^{*}$} \\
\hline & Disagree & 12 & 6 & \\
\hline & Not sure & 45 & 23 & \\
\hline & Agree & 93 & 47 & \\
\hline & Strongly Agree & 48 & 24 & \\
\hline \multirow{5}{*}{$\begin{array}{l}\text { A visit is tactfully promoting awareness on } \\
\text { wildlife tourism and conservation }\end{array}$} & Strongly disagree & 3 & 2 & \multirow{5}{*}{$40.1^{*}$} \\
\hline & Disagree & 9 & 5 & \\
\hline & Not sure & 22 & 11 & \\
\hline & Agree & 89 & 45 & \\
\hline & Strongly Agree & 77 & 39 & \\
\hline \multirow{5}{*}{ Life animal's show is part of wildlife tourism } & Strongly disagree & 5 & 3 & \multirow{5}{*}{$37.3^{*}$} \\
\hline & Disagree & 9 & 5 & \\
\hline & Not sure & 28 & 14 & \\
\hline & Agree & 89 & 45 & \\
\hline & Strongly Agree & 69 & 35 & \\
\hline
\end{tabular}




\begin{tabular}{|c|c|c|c|c|}
\hline \multirow{5}{*}{$\begin{array}{l}\text { Life animals' show tactfully conscious about } \\
\text { important of wildlife conservation }\end{array}$} & Strongly disagree & 5 & 3 & \multirow{5}{*}{$37.5^{*}$} \\
\hline & Disagree & 7 & 4 & \\
\hline & Not sure & 29 & 15 & \\
\hline & Agree & 85 & 43 & \\
\hline & Strongly Agree & 74 & 37 & \\
\hline \multirow{5}{*}{ Entrance fee is a tourism and conservation fee } & Strongly disagree & 4 & 2 & \multirow{5}{*}{$36.7^{*}$} \\
\hline & Disagree & 11 & 6 & \\
\hline & Not sure & 34 & 17 & \\
\hline & Agree & 94 & 47 & \\
\hline & Strongly Agree & 57 & 29 & \\
\hline \multirow{5}{*}{ It is a beneficial trip } & Strongly disagree & 7 & 4 & \multirow{5}{*}{$34.6^{*}$} \\
\hline & Disagree & 12 & 6 & \\
\hline & Not sure & 31 & 16 & \\
\hline & Agree & 89 & 45 & \\
\hline & Strongly Agree & 61 & 31 & \\
\hline \multirow{5}{*}{ The information of wildlife is sufficient } & Strongly disagree & 6 & 3 & \multirow{5}{*}{$32.3^{*}$} \\
\hline & Disagree & 23 & 12 & \\
\hline & Not sure & 43 & 22 & \\
\hline & Agree & 92 & 46 & \\
\hline & Strongly Agree & 36 & 18 & \\
\hline \multirow{5}{*}{ Learn about wildlife tourism and conservation } & Strongly disagree & 1 & 1 & \multirow{5}{*}{$47.5^{*}$} \\
\hline & Disagree & 5 & 3 & \\
\hline & Not sure & 34 & 17 & \\
\hline & Agree & 119 & 60 & \\
\hline & Strongly Agree & 41 & 21 & \\
\hline \multirow{5}{*}{$\begin{array}{l}\text { Protecting the wildlife ultimately carrying out } \\
\text { tourism and conservation activities }\end{array}$} & Strongly disagree & 2 & 1 & \multirow{5}{*}{$42.4^{*}$} \\
\hline & Disagree & 1 & 1 & \\
\hline & Not sure & 27 & 14 & \\
\hline & Agree & 84 & 42 & \\
\hline & Strongly Agree & 86 & 43 & \\
\hline & In to & 200 & 100 & \\
\hline
\end{tabular}

Note: $*$ Mean $=40$

\section{References}

1. UNWTO World Tourism Barometer (World Tourism Organization). November 2012 (2012) (Volume10),http://dtxtq4w60xqpw.cloudfront.net/sites/all/files//unwto_barom12_06_nov_excerpt .pdf. Retrieved at 6 June 2014.

2. Tourism Malaysia: Tourist Arrivals and Receipts to Malaysia (2012a). http://corporate.tourism.gov.my/research.asp?page=facts_figures. Retrieved at 6 June 2014

3. Tourist Arrivals in Sabah (2012b). http://kepkas.sabah.gov.my/2012/02/13/sabah-tourist-arrivals. Retrieved at 18 June 2014

4. Daily Express: Sabah Tourist Receipts http://www.dailyexpress.com.my/news.cfm?NewsID= 86861. Retrieved at 18 June 2014

5. One Stop Malaysia: Lok Kawi Wildlife Park (2008). http://www.onestopmalaysia. com/travel/sabah/lok-kawi-wildlife-park.html. Retrieved at 18 January 2014

6. D. Newsome, R. Dowling, S. Moore, Wildlife Tourism: Aspect of Tourism. Channel View Publication, Toronto (2005)

7. K. Kutay, Brave new role: Ecotour operators take centre stage in the era of green travel. In Going Green: The Ecotourism Research for Travel Agents. Supplement to Tour and Travel News. October 25:80 (1993)

8. C. Ryan, Saltwater crocodile as tourist attractions. Journal of Sustainable Tourism, 6, 4, 339 (1998)

9. C. S. Corazon, Zoo Tourism: Biodiversity Conservation Through Tourism. Journal of Ecotourism, 7, 2, 160 (2008) 
10. J. Cherfas, Zoo 2000- A look beyond the bars, British Broadcasting Corporation, London (1984)

11. C. M. Hall, B. Weiler, What's so special About Special Interest Tourism? In Special Interest Tourism, B. Weiler \& C.M. Hall (Eds.), Belhaven Press, London, UK (1992)

12. S. Bitgood, D. Patterson, A. Benefield, Exhibit design and visitor behavior; Empirical relationship. Environment and Behaviour, 20, 4, 474 (1988)

13. G. Broad, Visitor profile and evaluation of informal education at Jersey Zoo. Dodo Journal of Wildlife Preservation Trusts, 32, 166 (1996)

14. K. Higginbottom, Wildlife Tourism: Impacts, Management and Planning. Common Ground Publishing (2004)

15. A. Bright, C.L Pierce, Information and education for managing wildlife viewing in Wildlife viewing: A Management Handbook. Ed. J. Manfredo, Oregon State University Press, Corvallis, Oregon (2002)

16. K. Markwell, B. Weiler, Ecotourism and interpretation in Contemporary Issues in Heritage and Environmental Interpretation. Ed. D. Uzzell \& R. Ballantyne, The Stationary Office, London (1998)

17. G. Moscardo, Bird watching as a Tourist Activity in the Great Barrier Reef Region. Unpublished report. Townsville; CRC Reef Research Centre (1997)

18. M.D. Kreger, J.A. Mench, Visitor-animal interactions at the zoo, Anthrozoos, 8, 3, 143 (1995) 